\title{
The Loyal Republic: Traitors, Slaves and the Remaking of Citizenship in Civil War America
}

Review Number: 2276

Publish date: Thursday, 23 August, 2018

Author: Erik Mathisen

ISBN: 978-1469636320

Date of Publication: 2018

Price: $£ 25.81$

Pages: 256pp.

Publisher: University of North Carolina Press

Publisher url: https://www.uncpress.org/book/9781469636320/the-loyal-republic/

Place of Publication: Chapell Hill

Reviewer: Tom Lawrie

In The Loyal Republic, Erik Mathisen attempts to redefine the way Americans saw themselves, their citizenship and loyalty in the Civil War era. Mathisen ably demonstrates the loose conglomeration of states that existed in 1861 and the tenuous link the average American had to the federal state, as well as the emphasis placed on state loyalty by proto-Confederates during the secession crisis, and the redefinition of American citizenship prompted by the secession of the Confederate states in the North. Mathisen 'examines the debate over citizenship that the Civil War set in motion' (p. 9), both by scouring the national macrosocietal and political consciousness and the localised debates in Mississippi which he has chosen as a statelevel case study.

Mathisen's modus operandi in this book is to study 'the ways in which loyalty - as a political act, a language, and a bundle of state policies - became part of a larger attempt to redefine citizenship and reckon with the power of nation-states, all at once' (p. 2). Loyalty has long formed a niche in Civil War scholarship, holding the interest of Civil War historians under the inexorable bulk of military histories and biographies. Works such as Christian J. Samito's Becoming American Under Fire: Irish Americans, African-Americans and the Politics of Citizenship During the Civil War Era have recently touched on the notion of citizenship and loyalty, with Samito conceptualizing a citizenship whereby loyalty 'trumped race, color, and ethnicity in defining who belonged to the American people'.(1) Mathisen takes these broad strokes and broadens them further, setting the concept of loyalty as the cornerstone of American citizenship as long as it remained relevant in the war-stricken society. It is impossible to argue that the Civil War did not redefine the relationship between the American government and its people. Where Mathisen succeeds in this book, however, is to demonstrate just how much of an onus was placed on loyalty, or as he puts it, how various classes of Americans 'attempted to reckon with the power of states by using a politicized language of loyalty' (p. 3). The Loyal Republic charts not just what being a citizen entitled 19th-century Americans to; but what responsibilities it required of them to subjugate a rebellion. It also demonstrates the profound effect the secession crisis and the Civil War had on the definition of citizenship, and how the burden placed on loyalty slowly receded as the rebellion was subdued.

Mathisen's first chapter looks at the definition of citizenship in the early republic, the painting the picture of 
an early-19th-century American government inexorably separate from its citizens, benefitting only from the rights set forth by the inconsistent founding documents that created the federal state just decades previous. The title of the chapter, 'A government without citizens,' speaks volumes for its contents, and frames the attitudes of 19th-century Americans toward their government that Mathisen defines. When they thought of their citizenship at all, he argues, 'it was their connection to the smaller republics that made up the Union that commanded most of their attention' (p. 13). With this ambiguity came problems, and the Jeffersonian system of small government which won out over the Federalists in the early 19th century and the apparent invisibility of the state was fiction. The rapid expansion of the early republic was controlled by the national government from the shadows. By the time of secession, Mathisen argues, sectionalism had dissolved 'the few, fragile ties that connected Americans to the national government' (p. 35). The South began creating a new citizenship tied to the nascent Confederacy, while the North clung to what was left of its own republic and developed their own understanding of what it meant to be an American, driven by the need to create independence or defend the republic from rebellion, accordingly. As the Civil War began, fuelled by the treachery of the South or disillusionment with the federal government respectively, loyalty came to the forefront of defining what made citizens of the two republics.

The second chapter moves its attention to Mississippi, focusing on the rise and fall of the state government during the secession crisis, the onus placed on state loyalty and the Mississippi government's eventual downfall and how it was subsumed into the Confederacy. The work of John Pettus to establish a Republic of Mississippi and its eventual absorption by the Confederacy are laid out, with the Mississippian republic quickly becoming 'a shell, with the flimsiest claim to sovereignty' (p. 40) as Pettus failed to command the loyalty of the people, and in time, 'the national project of Confederate state formation would ... engulf Mississippi and render its state government superfluous' (p. 63). Pettus would leave the state to be decimated by occupying Union forces as he fled, his dreams of a Republic of Mississippi lying in the dust as a failed state.

The third chapter focuses on the Confederate use of the military as a tool to define its own nascent citizenship, using the martial collective experience of its hundreds of thousands of young soldiers to reeducate the masses in uniform as Confederate citizens. Confederate citizenship was organised much in the way of its armies, piecemeal and arbitrarily, under the cosh of nationalist rhetoric and pressure from the growing power of the North. Mathisen's argument here is how the Confederate state built a military machine, which it then used as a tool to school its recruits in citizenship, bringing white southerners to understand what it meant to be a citizen of the new Confederate States of America, and using starkly defined loyalty to delineate between the 'ideal citizens' and 'stateless cowards' and create 'a powerful kind of citizenship that would outlast the Civil War and leave a lasting mark' (p. 67). It was this deeply entrenched idea of loyalty to the inchoate Confederacy which would form the fertilizer for the Lost Cause to root itself in, complicating the attempt by the federal government to re-indoctrinate unrepentant white southerners after the fall of the Confederacy in 1865.

The fourth chapter begins to look at the occupation of Mississippi, and the growth of the American nationstate throughout the Civil War. Mathisen ably demonstrates the furore in the North with the South's treachery, prompting Americans to rethink loyalty to the state. 'It was a struggle in and out of government over who could be counted as loyal, what rights the disloyal ought to possess, and what citizenship meant in what was left of the nation' (p. 88), and the American public recognised that even if they triumphed over the seceded states, the republic may never be the same as what it once was. Loyalty became the watchword for many, although outlining treason was much more complicated in practice. While Abraham Lincoln developed his intent to bring the southern states back into the fold status quo antebellum, the mood of the public became sourer and sourer as the war drew a horrific toll, and many began to 'mention a more stringent, more unsparing set of rules regarding citizenship that would, by the war's end, leave white southerners in no doubt that their failure in national independence would make them outsiders in a postwar republic' (p. 89). Mathisen also discusses the actions of former slaves, contrabands and freedpeople, who used the meaning of loyalty and citizenship to great effect. Against the current of patronizing, paternalistic attitudes from white Union officers, they established themselves as loyal subjects for reasons twofold: to 
damage the reputations of their former owners and 'to secure a more durable bond with the American state' (p. 105). They enlisted in droves, serving under white officers of varying competence, and developed a political relationship with the state, ending the war as 'the vanguard in a new, loyal, colonial South' (p. 116).

The fifth chapter moves into Reconstruction, with Andrew Johnson's attempt to frame loyalty as the benchmark for citizenship as the subjugated white South attempted to reclaim their rights as Americans the focal point. The war ended sourly, with the Unionist demand for a pound of flesh accentuated by Lincoln's assassination at the hand of a Confederate sympathizer. In his place, Johnson, a staunchly Unionist Democrat from Tennessee, took a much harder line on the disloyal during the war, ensuring those who wanted to be enfranchised had to have taken part in the destruction of the receding Confederacy. Johnson was, as Mathisen posits, obsessed with loyalty, and believed firmly that the United States was a white man's republic. Once he came to power, his approach to loyalty was more deliberate, but his plans to reunite the country one oath at a time soon unravelled. His terms of amnesty were deemed too lenient, and left no room for African Americans. Loyalty itself was devalued by unrepentant Confederates 'who could only bring themselves to mouth the words, and by northerners who could not trust them' (p. 143). Despite being effectively ignored by Johnson's plan for Reconstruction, African Americans still plugged away at their battle for citizenship, and they had convinced many of their loyalty and allegiance, which led Americans to question whether this entitled them to 'rights over those of their former owners' (p. 144).

The final chapter examines the postwar struggle for property, as both whites and blacks laid claim to seized or destroyed property after the dust settled. Mathisen explores the Mississippi Valley and how the failed radical attempt to redistribute white land to the freedmen eroded concepts of loyalty throughout the state and undermined state power and national citizenship. Much of this chapter comes from Mathisen's contributory chapter to Bruce E. Baker and Brian Kelly's After Slavery: Race, Labor and Citizenship in the Reconstruction of the South.(2) The former slaves, of course, did not gain meaningful compensation after their emancipation. Whereas, Mathisen argues, they 'had used their loyalty as a crowbar to pry open the door of the state for access and meaningful power... by the early 1870 s that same tool was quickly losing its effectiveness' (p. 166). African Americans rested on the idea that their loyalty to the Union would afford them protection from the federal government, even if the federal government fell short of their expectations. As black children were pried from their families and indentured, apprenticeship became the new slavery, with little help from the state or federal authorities. Ultimately, loyalty would be detached from citizenship, and tests of allegiance or measures of loyalty would not be ingrained in the Constitution, in what Mathisen calls 'one of the most unusual issues in the history of the republic' (p. 166).

The scope of the work shuttles neatly between the nation and the Mississippian microcosm Mathisen has chosen as a case study. In focusing on Mississippi, Mathisen is able to dig deeper into the minutiae of antebellum, Civil War and Reconstruction citizenship in the state, but this does throw up questions about whether Mississippian attitudes were reflected in other parts of the Confederacy, or whether there was a drastic difference in Northern states. Owing to the different nature of different states in the antebellum era, and the varying degrees of reluctance or fervour with which the states legislated secession, there may be interesting parallels to draw for the future scholar.

Mathisen's methodological approach to this work draws on a wide range of sources, and the book ultimately benefits from truly sound research. By focusing on contemporary newspapers, letters, magazines, the Congressional Globe, official records of secession conventions and diaries, the work possesses a rich primary source based from which Mathisen constructs his argument. Where he touches on themes already bolstered by a strong historiography, Mathisen expertly deconstructs the sources and ideas previously laid down in the footnotes, demonstrating a strong understanding of the core ideas and themes that underscore the book.

Ultimately, The Loyal Republic works because it is balanced. Mathisen expertly brings the reader's focus in and out of the national scale, concentrating alternately on the federal government and its own grandiose depictions and definitions of citizenship and loyalty, before zooming in on Mississippi and exploring how 
these grandiose definitions filtered down and affected everyday Americans. This prevents the work from becoming too broad or too narrow, finding the equilibrium between the government and its people, just as he argues that the relationship between the two changed in the crucible of war. The fundamental questions that Mathisen seeks to answer, namely the ways in which loyalty became a part of the ways in which citizenship was redefined in the Civil War era, are clearly defined, as the tumultuous bond between loyalty and citizenship is tracked over time. Exploding in 1861 with the challenge to the national government from the Confederate States, it became the litmus test for obtaining or retaining citizenship until it slowly receded in the late 1860s and 1870s. However, as Mathisen finishes, loyalty never fully went away, but was 'folded into vague debates over the future of the nation and the place of foreigners in it' (p. 174). As children today pledge their allegiance to the Flag and the Republic for which it stands, Mathisen's work bears fruit in understanding the link between loyalty and citizenship today, showing that even in 'a republic founded on the principle of personal liberty' where 'reckoning with a nation-state is perhaps the one argument that might never be settled' (p. 175), Americans going through the Civil War still attempted to redefine the relationship between the nation and its people. Because of this link to the modern United States, placing the study of the Civil War in the context of the United States as a whole, is why The Loyal Republic is a welcome addition to any bookshelf.

\section{Notes}

1. Christian J. Samito, Becoming American Under Fire: Irish Americans, African Americans, and the Politics of Citizenship during the Civil War Era, (Ithaca, NY, 2009), p. 234.Back to (1)

2. Erik Mathisen, "'It Looks Much Like Abandoned Land": Property and the Politics of Loyalty in Reconstruction Mississippi', in After Slavery: Race, Labor, and Citizenship in the Reconstruction South, ed. Bruce E. Baker and Brian Kelly, (Gainesville, FL, 2013), pp. 77-97.Back to (2)

Source URL:https://reviews.history.ac.uk/review/2276

\section{Links}

[1] https://reviews.history.ac.uk/item/298316 